\title{
1. BACKGROUND, OBJECTIVES, AND PRINCIPAL RESULTS OF MADEIRA ABYSSAL PLAIN DRILLING ${ }^{1}$
}

\author{
Shipboard Scientific Party ${ }^{2}$
}

\section{INTRODUCTION}

Abyssal plains are flat areas of ocean floor located in the deepest parts of the deep-sea basins. They were not recognized as distinct seafloor features until 1949 (Tolstoy and Ewing, 1949) when more precise and near continuous collection of bathymetric data became available, augmenting intermittent soundings. The first cores taken from abyssal plains revealed sediments containing sands with displaced shallow water foraminifers (Locher, 1954; Phleger, 1954), revealing that the plains were formed by the infilling of deep basins. Studies by Belderson and Laughton (1966) and Horn et al. (1971, 1972) showed the importance of turbidity currents in forming abyssal plains in the Atlantic, Pacific, and Mediterranean regions. The turbidites deposited from these currents frequently differ from the classic Bouma sequences (Bouma, 1962) in having very thick ungraded mud overlying relatively thin silty and sandy bases. This is because these flows are gigantic in magnitude and travel long distances before reaching their final destination. Their coarse load is dumped at the edges of the abyssal plain with the mud continuing into the basin to pond as a laterally extensive layer up to several meters thick (Weaver and Rothwell, 1987). Individual turbidites with volumes of $100 \mathrm{~km}^{3}$ or more are frequently encountered (Elmore et al., 1979; Rothwell et al., 1992).

The study of abyssal plains was boosted when the Site Assessment Task Group of the Nuclear Energy Agency's Seabed Working Group (Anderson, 1980) selected the Madeira Abyssal Plain (MAP) for detailed study into the feasibility of disposal of heat-emitting radioactive waste. This initiated a series of cruises to the area, mounting a planned program of research including geophysical, geological, and geochemical investigations between 1980 and 1988 (Schuttenhelm et al., 1989; Freeman 1989; Weaver and Thomson, 1987). MAP has become one of the most intensively studied areas of seafloor in the oceans, and its study has resulted in the development of several new models that explain the sedimentology and geochemistry of deep-sea sediments. Comprehension of how sediments are transported and deposited as mass flows, how early diagenetic processes progress, and how abyssal plains record basin histories led directly to the abyssal plain drilling proposal.

Drilling the Madeira Abyssal Plain (MAP) was designed to determine the Neogene erosional history of the Canary Basin by recovering sediments from the abyssal plain, with hopes that it will provide insights into links between mass sediment wasting on continental margins and climate/sea-level change. It has addressed one of the fundamental questions in the sea-level debate: What is the volume and frequency of continental margin erosion? MAP drilling should yield an assessment of the volume and frequency of individual sediment flows and an interpretation of early diagenesis in a sequence of mixed sediment types. In many ways this turbidite system represents

Schmincke, H.-U., Weaver, P.P.E., Firth, J.V., et al., 1995. Proc. ODP, Init. Repts., 157: College Station, TX (Ocean Drilling Program).

${ }^{2}$ Shipboard Scientific Party is given in the list preceding the Table of Contents. the opposite extreme to turbidite deposition on submarine fans that have been studied on several recent ODP legs (Legs 96, 116, 155). MAP turbidites are not only large, with volumes of tens to hundreds of cubic kilometers, they are typically fine grained and are deposited infrequently. MAP drilling will also provide important modern analogues for interpreting the ancient rock record.

\section{Geophysical and Geological Setting}

The Canary Basin covers an area of $3.36 \times 10^{6} \mathrm{~km}^{2}$ (Rothwell et al., 1992) and is bounded by the lower flank of the Mid-Atlantic Ridge (MAR) in the west, the Azores-Gibraltar Rise (part of the European/African plate boundary) in the north, the Madeira-Tore Rise in the northeast, and the Cape Verde Rise in the south. This basin includes the Canary Islands and Madeira together with the Cruiser/Hyeres/Great Meteor seamount chain (von Rad, 1974) in the west, as well as a $1500 \mathrm{~km}$ stretch of the northwestern African margin.

The Madeira Abyssal Plain lies in the deepest part of the Canary Basin at a water depth of $5400 \mathrm{~m}$ and occupies a 400 (north-south) $\times$ 200 (east-west) km area (Fig. 1). The abyssal plain is bounded by hills to the west, south, and north, and by a sharp change of slope to the east from the very gentle gradient of the rise (about 1:300 to $1: 1000$ ) to the virtually flat (less than 1:3000) abyssal plain (Searle, 1987). The Charis and Cruiser fracture zone valleys extend westward from the plain between the hills of the MAR flank. Locally the abyssal plain is interrupted by abyssal hills a few hundred meters high and

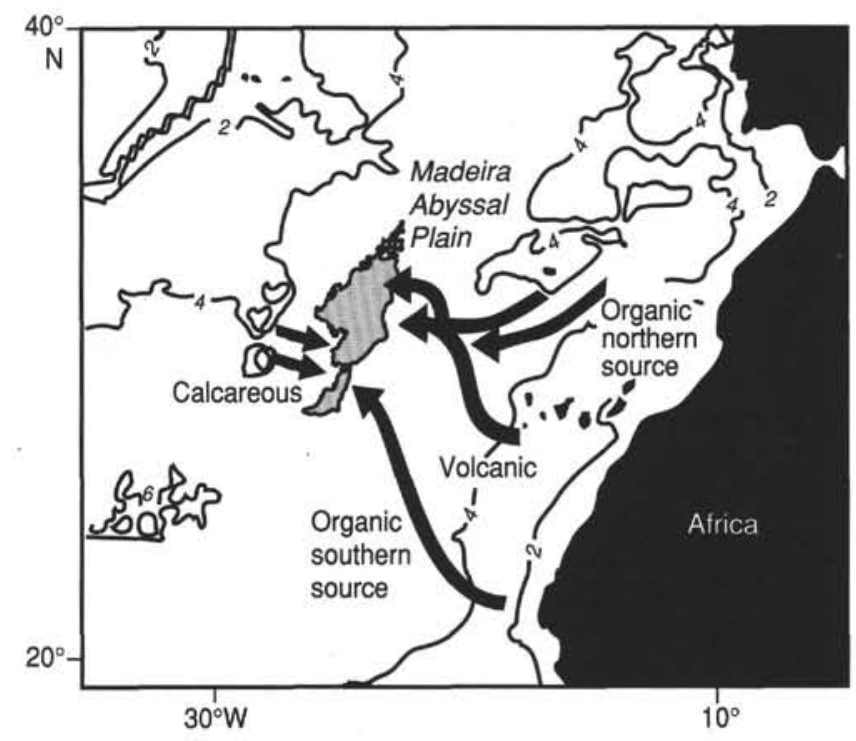

Figure 1. Location of the Madeira Abyssal Plain and sources of turbidites. Contours in kilometers. 
a few tens of kilometers across, nearly all draped by hemipelagic sediment (Fig. 2). This hemipelagic drape averages $200 \mathrm{~m}$ in thickness and is expected to consist predominantly of hemipelagic clay (Weaver et al., 1986; Searle, 1987). Turbidites have infilled this draped topography, lying conformably on the drape in the deeper parts of the basins, but resting with a clear unconformity where the hills rise up steeply (Fig. 3). The turbidite sequence averages $350 \mathrm{~m}$ in thickness, except in a few deep areas where it may reach $530 \mathrm{~m}$, and it varies from being strongly acoustically laminated near the top to poorly stratified to transparent near the base (Duin and Kuijpers, 1983).

\section{Principal Characteristics of MAP Sediments}

Previous studies of late Quaternary sediment flows on the MAP have shown several characteristics that make this abyssal plain ideal for further investigation. The flows are large, often depositing on the order of $100-200 \mathrm{~km}^{3}$ of sediment on the abyssal plain. These large volumes spread across the whole abyssal plain, and thus individual flows can be correlated from site to site and their volumes can be calculated. They are also fine grained, except in the proximal parts of the plain, and their deposition causes little or no erosion of the underlying beds.

These turbidites fall into three compositional groups related to distinct source areas. Organic-rich turbidites derive from the upwelling cells off the northwest African margin and have two sources, one north and one south of the Canaries (Fig. 1). The oxidation front mechanism results in bicolored turbidite units, usually olive green below the relict oxidation front where the organic material remains, and pale green above where the organic material has been oxidized. Volcanic turbidites derive from the volcanic islands of the Canaries
Figure 2. Bathymetric map of the central part of the Madeira Abyssal Plain. Contours in corrected meters.
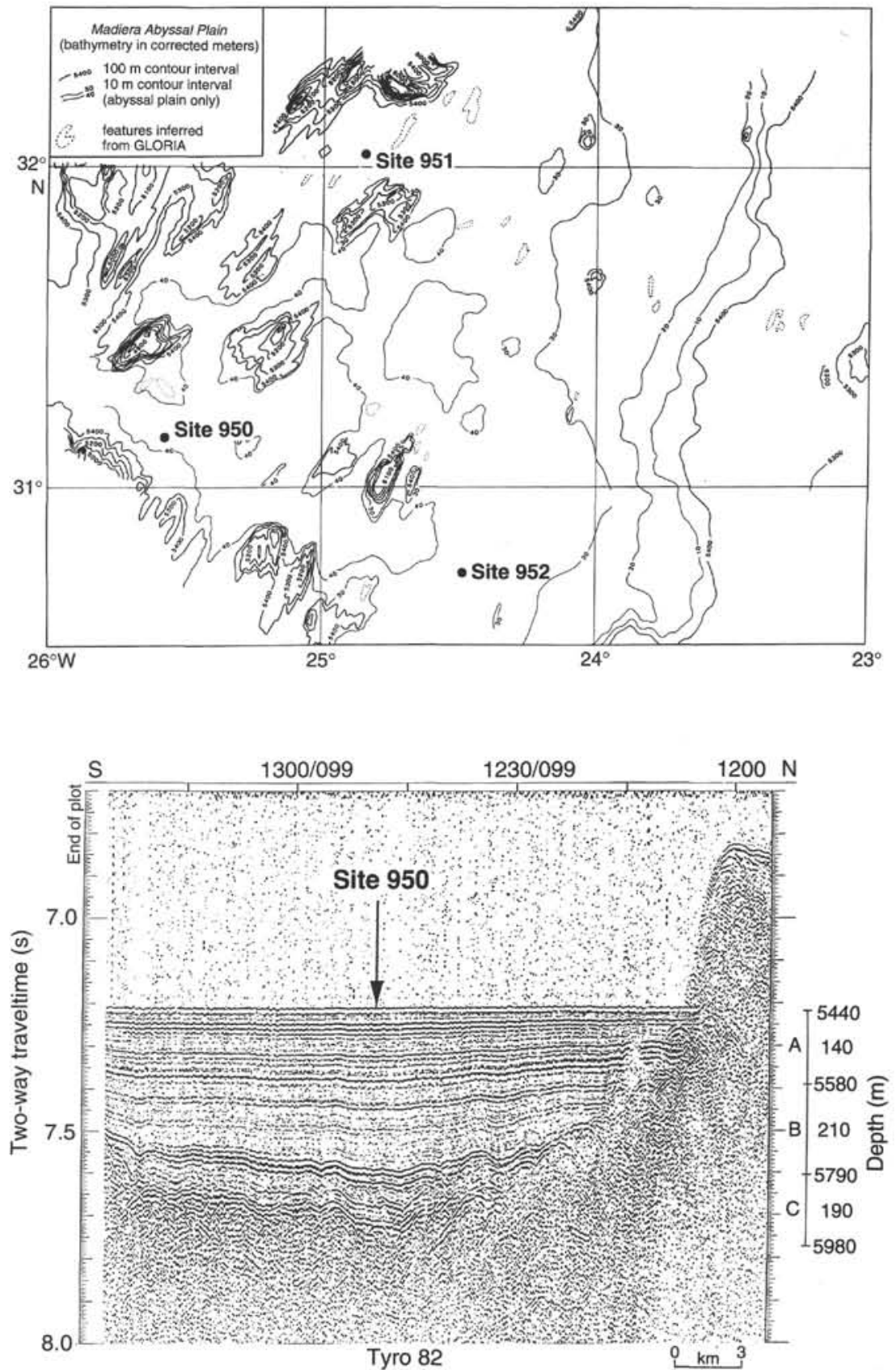

Tyro 82
Figure 3. Part of Tyro 1982 seismic reflection profile showing location of Site 950. 
and/or Madeira. The white calcareous turbidites derive from the Cruiser/Hyeres/Great Meteor seamount chain to the west of the abyssal plain.

The turbidites are separated by thin pelagic layers that often represent several tens of thousands of years. These layers consist of calcareous ooze, marls, or clay, depending on the carbonate compensation depth (CCD) at the time of deposition. The CCD is closely controlled by the general circulation of the oceans and has oscillated through the last $2.5 \mathrm{Ma}$ in phase with climatic shifts. During interglacials the $\mathrm{CCD}$ was lower, allowing increased preservation of calcium carbonate in the North Atlantic. Conversely, during glacial periods, and also prior to $2.6 \mathrm{Ma}$, the $\mathrm{CCD}$ was shallower, giving rise to poorer preservation and frequently no preservation at all of calcium carbonate. In the last $730,000 \mathrm{yr}$ many of the turbidites were deposited at the boundaries of these pelagic sediment types suggesting a link between climate and sea-level change and sediment stability.

Recent research has shown that the MAP turbidites may be associated with debris flows deposited on the continental margin (Weaver et al., 1995). These two types of deposits represent the two principal processes that transport sediments from the mass wasting event. Debris flows leave a trail of sediment across the continental slope and rise, in some cases, all the way to the edge of the abyssal plain (Masson et al., 1992). The large turbidity curren.s, however, cross the continental slope and rise without depositing, eventually becoming trapped by the topography of the abyssal plain. Smaller turbidity currents may be entirely channelized from source to abyssal plain, but the larger flows appear to travel as sheets with only their coarse sandy components being channelized (Masson, 1994).

One of the most recent turbidites on the MAP (turbidite $b$ of Weaver and Kuijpers, 1983) has a volume of $125 \mathrm{~km}^{3}$ and has been linked to the Canary Debris Flow which itself has a volume of over $400 \mathrm{~km}^{3}$ (Masson et al., 1992; Masson, 1994). These two flows originated as a major collapse event from the northern side of the westernmost Canary Island of Hierro. Thus the Canary Islands erode in similar ways to the Hawaiian Islands, namely through massive mass wasting events, and the products of these accumulate in different areas on the continental rise and as stacked turbidites in the abyssal plain. The northwestern African continental margin also erodes by large scale mass wasting (Embley, 1982), and many of the organicrich turbidites may be related to organic-rich debris flows. The abyssal plain acts as a recorder of all these major mass wasting events that have taken place within the Canary Basin and allows estimates to be made of their frequencies and volumes, which can be used to model sediment transport budgets for the whole basin.

\section{OBJECTIVES}

The objectives of Leg 157 included the following:

1. Dating the inception of the Madeira Abyssal Plain.

2. Determining the frequency of turbidite deposition on the Madeira Abyssal Plain.

3. Generating mass balance calculations for sediment erosion and redeposition within the Canary Basin.

4. Analyzing the long term effects of sediment burial and diagenesis in a sequence of mixed volcanic, organic-rich, and organic-poor sediments.

5. Determining the history of the $\mathrm{CCD}$ in one of the deepest areas drilled in the North Atlantic.

\section{PRINCIPAL RESULTS}

\section{Dating the Inception of the Abyssal Plain}

One of our major objectives was to establish the age of the onset of turbidite deposition. This is seen on the seismic profiles as a major reflector, R4 of Duin and Kuijpers (1983), which divides the draped sediments beneath from the parallel laminated sediments above (Fig. 3 ). This reflector appears to be correlated with a major change in erosional style within the Canary Basin. We drilled through this reflector at each site and found it to coincide with a series of thick sands at the base of thick mud turbidites. The youngest of these sandy units appears to correlate between each site, forming a very distinctive color graded unit. At Site 950 it is more fully developed and forms a 10.5 $\mathrm{m}$-thick calcarenite, apparently derived from the seamounts to the west. The age of this unit of sandy turbidites has not been precisely determined and awaits further shore-based work. However, the thick calcarenite has an age between 10.3 and $13.6 \mathrm{Ma}$ in Site 950 and appears to be somewhat younger than 13.1 Ma in Sites 951 and 952 . The downward transition from turbidites to red clay at Site $950 \mathrm{oc}-$ curs between 11.3 and $15 \mathrm{Ma}$ (probably toward the younger age). In Sites 951 and 952 thick sequences of green turbidites were found beneath the R4 reflector, but these were not drilled beyond $13.1 \mathrm{Ma}$. Thus the early infilling of the abyssal plain may have taken place in the deeper parts of the fracture zone valleys (Sites 951 and 952) by relatively small flows all of which are green and probably derive from the northwestern African margin. The widespread flooding of turbidites and hence increased erosion within the Canary Basin began between 11.3 and $15 \mathrm{Ma}$.

\section{Determining the Frequency of Turbidite Deposition on the Madeira Abyssal Plain}

The second major objective was to test the relationship between continental margin erosion and climate/sea-level change over a longer time period than is accessible to piston coring. High resolution stratigraphy will show whether there is a relationship between turbidite emplacement and oxygen isotope stage boundaries. The most detailed biostratigraphic record has been produced for Site 950, although this, and the stratigraphic data for the other two sites, will be improved by shore-based work. The high rate of accumulation (42 $\mathrm{m} / \mathrm{m} . \mathrm{y}$.) measured in piston cores (Weaver et al., 1992) continues from 0-3 Ma. A lower rate of $28 \mathrm{~m} / \mathrm{m}$.y. was determined from 3-6.5 Ma with a much reduced rate of $9 \mathrm{~m} / \mathrm{m}$.y. between 6.5 and about 9$10 \mathrm{Ma}$. Rates between 9-10 Ma and the base of the turbidite sequence average about $21 \mathrm{~m} / \mathrm{m}$.y. It should be noted, however, that these rates apply to the combined turbidite sequence of organic, volcaniclastic, and calcareous turbidites. Rates for individual sources have not been produced so far. One major change apparent in the core logs is the low level of volcaniclastic turbidite input prior to $6.5 \mathrm{Ma}$. This age approximates the age of the shield development of Tenerife and may indicate that turbidites from the older islands east of Tenerife were prevented from reaching the MAP by a now buried barrier.

\section{Mass Balance Calculations for Sediment Erosion and Redeposition within the Canary Basin}

Our aim was to drill through the 350 -m-thick turbidite fill at three sites, spaced across the plain, so that individual turbidite units could be correlated and mapped across the plain with the aid of the dense seismic network. This will provide estimates of volumes of individual flows and their frequency will be determined by high resolution stratigraphy. These data can then be used to infer the erosional history of the whole basin (i.e., the volume of sediment eroded from each source per unit time over the last several million years).

Core correlation between the three sites will be facilitated by the excellent recovery that will provide a nearly $100 \%$ record of the abyssal plain sequence. Most of the work involved in mapping individual turbidites will be conducted ashore, as will the refining of the stratigraphy. However, we can already see that many units correlate and that some flows were very large (e.g., an 11-m-thick volcaniclastic turbidite between $189-200$ mbsf in Site 952 probably correlates with a similar unit between 192-200 mbsf in Site 951 and 193-199 mbsf in Site 950; Fig. 4). By analogy to the large flows already studied in the late Quaternary (Weaver et al., 1992), the volume of this single 
volcaniclastic turbidite probably exceeds $400 \mathrm{~km}^{3}$. Shore-based work will be aimed at correlating as many units as possible and providing estimates of their volumes. The downhole logs will enable us to tie turbidite groups to individual reflectors that we can then trace across the whole abyssal plain, thus aiding the volume calculations. Detailed geochemical work will divide the turbidites into compositional groups related to different sources, eventually allowing us to determine the volume of sediment derived from each source.

The late Quaternary piston core data shows an apparent correlation of turbidite input with sea-level/climate change, with single turbidites being deposited at each isotope stage boundary (Weaver and Kuijpers, 1983). We will not be able to assess whether this pattern continues throughout the sequence until further shore-based work has

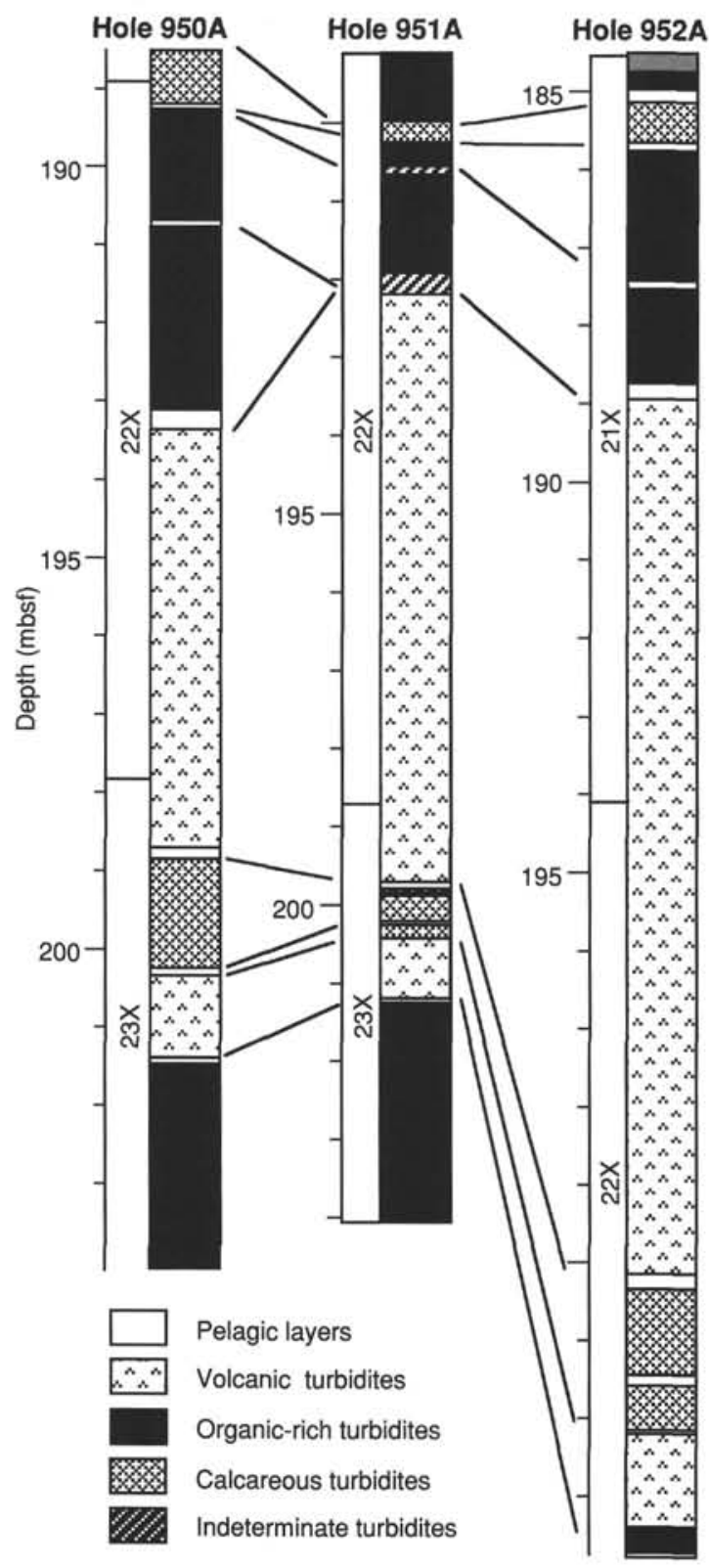

Figure 4. Correlation of part of the MAP turbidite sequence showing the same volcanic, organic-rich, and calcareous turbidites at all three sites $(950,951$, and 952). been completed. However, we can see that individual turbidites are separated by several centimeters to decimeters of pelagic sediment, indicating intervals of tens of thousands of years between their emplacement. An exception to this is in the deeper parts of Site 952 where the thin green turbidites have just a few millimeters of pelagic sediment between successive flows. In the upper part of Site 952 and throughout Sites 950 and 951 , two turbidites rarely lie adjacent to each other without a significant pelagic layer between. One of the surprising discoveries is that the turbidites were deposited throughout the early Pliocene, although at a slightly reduced rate compared to the late Pliocene/Quaternary. This period is generally regarded as having a relatively stable climate/sea-level.

\section{Analyzing the Long Term Effects of Sediment Burial and Diagenesis in a Sequence of Mixed Volcanic, Organic-rich, and Organic-poor Sediments}

Most of the geochemical analyses of diagenesis will be conducted post-cruise. However, pore-water was analyzed at a higher density than normal on ODP cruises and the results show remarkably consistent patterns between the three MAP sites, 950-952 (Fig. 5). Despite the deep-water $(5.4 \mathrm{~km})$ setting and low pelagic sedimentation rates $(0.4-0.6 \mathrm{~cm} / \mathrm{ka})$, pore-water data reveal the great importance of bacterially mediated oxidation of organic matter, located principally in organic-rich turbidites, in controlling diagenetic environments. Active sulfate reduction and methanogenesis are documented for the first time in this area. Resulting changes in pore-water chemistry modify carbonate equilibria, causing the precipitation of calcite and dolomite, while the dissolution of biogenic silica and volcanic glasses lead to the appearance of new silicate minerals, principally smectites and zeolites.

The distributions of alkalinity, sulfate, ammonia, and methane provide direct evidence of the nature and rates of organic-matter degradation. Suboxic bacterial processes produce alkalinity maxima in the upper $100 \mathrm{~m}$ of sediment, while Sites 951 and 952 additionally display much larger maxima in the organic-rich turbidites that lie at the bases of these holes. Decreasing pore-water sulfate (Fig. 5) and increasing ammonia concentrations with depth reveal the onset of sulfate reduction below $100 \mathrm{mbsf}$, with the degree of sulfate reduction increasing from the western (950) to the most eastern (952) site. The nonlinear nature of the pore-water profiles and the sulfate versus ammonia correlation (Fig. 6) suggest that seawater sulfate is diffusing toward a broad zone of sulfate reduction rather than a sharp redox interface. Significant methane was observed only at Site 952, where modest levels first occurred in sulfate-depleted suboxic pore waters, but the highest levels were observed in deeper, sulfate-reducing environments.

Pore-water calcium first decreases and then increases again toward the base of each sequence, while magnesium becomes depleted progressively over the entire section; so $\mathrm{Mg} / \mathrm{Ca}$ ratios peak around 80 mbsf (Fig. 5). Calcium enrichment is greatest and magnesium depletion least at the most oxic site, 950 ; the other two sites display similar concentrations and profiles. These trends indicate that calcite is precipitating under suboxic conditions below the alkalinity maxima. Rising calcium and falling $\mathrm{Mg} / \mathrm{Ca}$ ratios at intermediate depths suggest that dolomite is precipitating in the sulfate-reducing zone. Falling magnesium associated with rapidly rising calcium in the lower parts of each hole probably accompany the precipitation of smectites.

Pore-water silica profiles (Fig. 5) display a remarkable degree of uniformity in all of the MAP sites, confirming the high degree of control that lithology exerts on silica pore-water concentrations, combined with the spectacularly uniform nature of the sedimentary successions in the upper $250 \mathrm{~m}$ at all three sites. Dissolution of biogenic silica probably provides the main control on pore-water silica concentrations, although the dissolution of volcanic glass and the precipitation of smectites also affect silica contents. By contrast, po- 


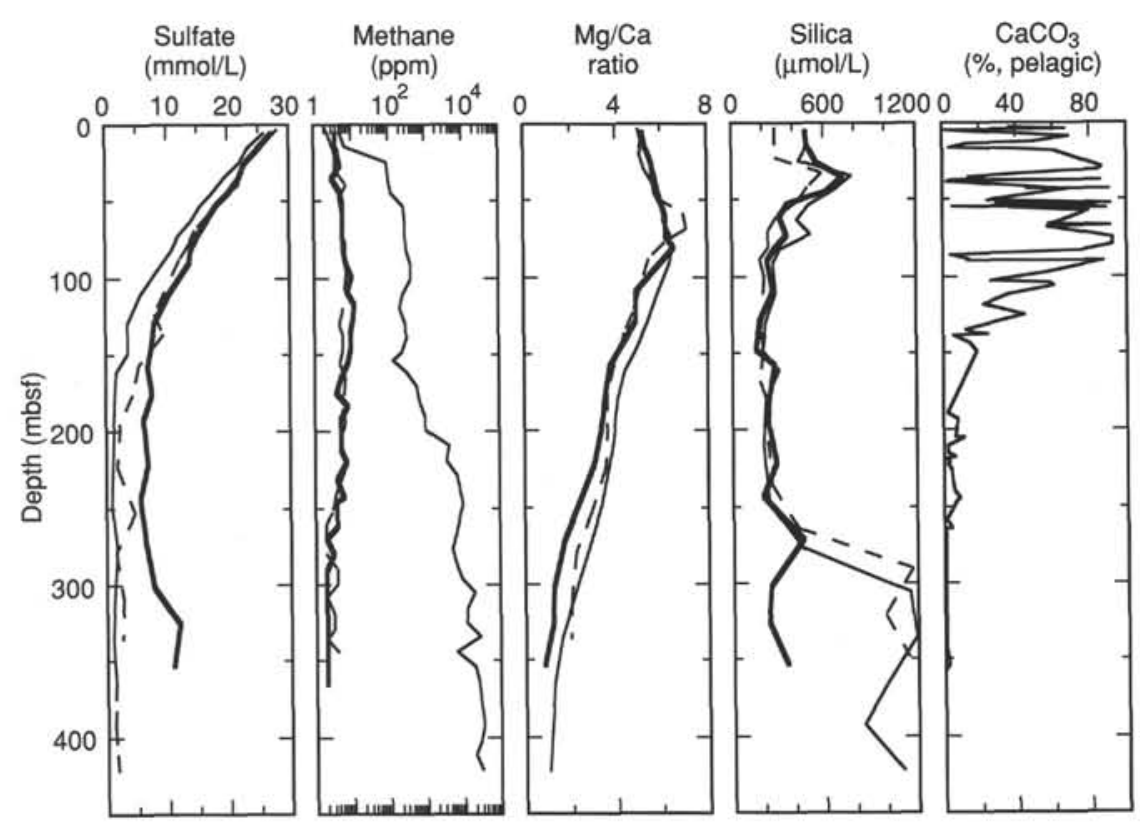

Figure 5. Comparison of geochemical profiles from squeezed pore-water samples. Heavy line $=$ Site 950 , dashed line $=$ Site 951 , thin line $=$ Site $952 . \mathrm{CaCO}_{3}$ graph for Site 950 only.

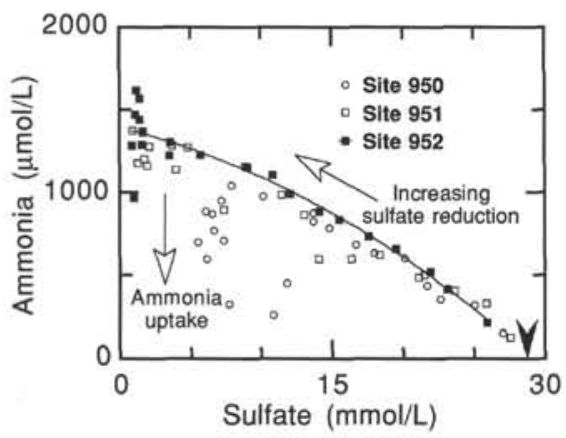

Figure 6. Ammonia/sulphate ratios for all three MAP sites. Filled arrowhead $=$ seawater value.

tassium concentrations display linear declines at all three sites, most likely in response to the precipitation of zeolite minerals, principally phillipsite, at the expense of volcanic glass in the more deeply buried parts of the successions.

\section{Determining the History of the CCD in One of the Deepest Areas Drilled in the North Atlantic}

The CCD is closely controlled by the general circulation of the oceans and has oscillated over the last $2.5 \mathrm{Ma}$ in phase with climatic shifts. Studies of ${ }^{13} \mathrm{C}$ trends in deep Atlantic cores have shown that the formation of the North Atlantic Deep Water (NADW) was suppressed during glaciations (Boyle and Keigwin, 1985), allowing corrosive southern-source water (Antarctic Bottom Water: AABW) to extend northward. There have also been lower frequency changes in the amount of dissolution through the Quaternary (Ruddiman et al, 1989; Kuijpers 1989). Prior to the onset of Northern Hemisphere glaciation at about $2.6 \mathrm{Ma}$, however, the level of the CCD in the North Atlantic appears to have been much shallower, preventing accumulation of calcareous pelagic sediment in the deeper basins.

The MAP sites provide an important pelagic sediment record in one of the deepest parts of the North Atlantic, which presently lies just above the level of the CCD and is therefore very sensitive to small changes in the level of the CCD. It has been shown that the turbidites cause little or no erosion of abyssal plain sediments (Weaver and Kuijpers, 1983) and thus the pelagic record interleaved between turbidites is essentially complete. This record has been reassembled and will be used to provide a detailed history of calcium carbonate preservation. Preliminary data show that calcium carbonate increases from very low values at about $3 \mathrm{Ma}$ to oscillating high and low values from 0-3 Ma (Fig. 5). Preservation is at its best through the latest Pliocene and early part of the Quaternary where marls alternate with oozes. In the latter part of the Quaternary marls tend to alternate with clays.

\section{REFERENCES}

Anderson, D.R. (Ed.), 1980. Proc. 5th Annu. NEA-Seabed Working Group Meeting: Albuquerque, NM (Sandia Natl. Lab.), Rep. SAND80-075.

Belderson, R.H., and Laughton, A.S., 1966. Correlation of some Atlantic turbidites. Sedimentology, 7:103-116.

Bouma, A.H., 1962. Sedimentology of Some Flysch Deposits: A Graphic Approach to Facies Interpretation: Amsterdam (Elsevier).

Boyle, E.A., and Keigwin, L.D., 1986. Comparison of Atlantic and Pacific paleochemical records for the last 215,000 years: changes in deep-ocean circulation and chemical inventories. Earth Planet. Sci. Lett., 76:135150.

Duin, E.J.T., and Kuijpers, A., 1983. Geological Studies on Abyssal Plains in the North Atlantic: Contrib. Seabed Working Group Progr. Rep. 1982, Internal Rep.: Haarlem (Rijks Geologische Dienst).

Elmore, R.D., Pilkey, O.H., Cleary, W.J., and Curran, H.A., 1979. Black shell turbidite, Hatteras Abyssal Plain, western North Atlantic ocean basin. Geol. Soc. Am. Bull., 90:1165-1176.

Embley, R.W., 1982. Anatomy of some Atlantic margin sediment slides and some comments on ages and mechanisms. In Saxov, S., and Nieuwenhuis, J.K. (Eds)., Marine Slides and Other Mass Movements: New York (Plenum), 189-213.

Freeman, T. (Ed.), 1989. Advances in Underwater Technology, Ocean Science, and Offshore Engineering (Vol. 18): Disposal of Radioactive Waste in Seabed Sediments. Soc. Underwater Tech., London (Graham and Trotman).

Horn, D.R., Ewing, M., Horn, B.M., and Delach, M.N., 1971. Turbidites of the Hatteras and Sohm Abyssal Plains, western North Atlantic. Mar. Geol., 11:287-323.

Horn, D.R., Ewing, J.I., and Ewing, M., 1972. Graded bed sequences emplaced by turbidity currents north of $20 \mathrm{~N}$ in the Pacific, Atlantic and Mediterranean. Sedimentology, 18:247-275. 
Kuijpers, A., 1989. Southern Ocean circulation and global climate in the middle Pleistocene (early Brunhes). Palaeogeogr., Palaeoclimatol., Palaeoecol., 76:67-83.

Locher, F.W., 1954. Ein beitrag zum Problem der Tiefseesande im westlichen Teil des aquatorialen Atlantiks. Heidelb. Beitr. Mineral. Petrogr., 4:135-150.

Masson, D.G., 1994. Late Quaternary turbidity current pathways to the Madeira Abyssal Plain and some constraints on turbidity current mechanisms. Basin Res., 6:17-33.

Masson, D.G., Kidd, R.B., Gardner, J.V., Huggett, Q.J., and Weaver, P.P.E., 1992. Saharan Continental Rise: sediment facies distribution and sediment slides. In Poag, C.W., and de Graciansky, P.C. (Eds.), Geologic Evolution of Atlantic Continental Rises: New York (Van Nostrand Reinhold), 327-343.

Phleger, F.B., 1954. Foraminifera and deep-sea research. Deep-Sea Res., 2:1-23.

Rothwell, R.G., Pearce, T.J., and Weaver, P.P.E., 1992. Late Quaternary evolution of the Madeira Abyssal Plain, Canary Basin, NE Atlantic. Basin Res., 4:103-131.

Ruddiman, W.F., Raymo, M.E., Martinson, D.G., Clement, B.M., and Backman, J., 1989. Pleistocene evolution: Northern Hemisphere ice sheets and North Atlantic Ocean. Paleoceanography, 4:353-412.

Schuttenhelm, R.T.E., Auffret, G.A., Buckley, D.E., Cranston, R.E., Murray, C.N., Shephard, L.E., and Spijkstra, A.E. (Eds.), 1989. Geoscience Investigations of Two North Atlantic Abyssal Plains: The ESOPE International Expedition (Vols. 1 and 2): Luxembourg (CEC-Joint Research Centre), JRC Report EUR.

Searle, R.C., 1987. Regional setting and geophysical characterization of the Great Meteor East area in the Madeira Abyssal Plain. In Weaver, P.P.E. and Thomson, J. (Eds.), Geology and Geochemistry of Abyssal Plains. Spec. Publ. Geol. Soc. London, 31:49-70.
Tolstoy, I., and Ewing, M., 1949. North Atlantic hydrography and the midAtlantic Ridge. Bull. Geol. Soc. Am., 60:1527-1540.

von Rad, U., 1974. Great Meteor and Josephine Seamounts (eastern North Atlantic): composition and origin of bioclastic sands, carbonate and pyroclastic rocks. "Meteor" Forschungsergeb. Reihe C, 19:1-62.

Weaver, P.P.E., 1994. Determination of turbidity current erosional characteristics from reworked coccolith assemblages, Canary Basin, North-east Atlantic. Sedimentology, 41:1025-1038.

Weaver, P.P.E., and Kuijpers, A., 1983. Climatic control of turbidite deposition on the Madeira Abyssal Plain. Nature, 306:360-363.

Weaver, P.P.E., Masson, D.G., Gunn, D.E., Kidd, R.B., Rothwell, R.G., and Maddison, D.A., 1995. Sediment mass-wasting in the Canary Basin. In Pickering, K.T., Hiscott, R.N., Kenyon, N.H., Ricci Lucchi, F., and Smith, R.D.A. (Eds.), Atlas of Deep Water Environments: Architectural Style in Turbidite Systems: London (Chapman and Hall), 287-296.

Weaver, P.P.E., and Rothwell, R.G., 1987. Sedimentation on the Madeira Abyssal Plain over the last 300,000 years. In Weaver, P.P.E., and Thomson, J. (Eds.), Geology and Geochemistry of Abyssal Plains. Geol. Soc. Spec. Publ. London, 31:71-86.

Weaver, P.P.E.. Rothwell, R.G., Ebbing, J.. Gunn, D., and Hunter, P.M. 1992. Correlation, frequency of emplacement and source directions of megaturbidites on the Madeira Abyssal Plain. Mar. Geol., 109:1-20.

Weaver, P.P.E., Searle, R.C., and Kuijpers, A., 1986. Turbidite deposition and the origin of the Madeira Abyssal Plain. In Summerhayes, C.P., and Shackleton, N.J. (Eds.), North Atlantic Palaeoceanography. Spec. Publ. Geol. Soc. London, 21:131-143.

Weaver, P.P.E., and Thomson, J. (Eds.), 1987. Geology and Geochemistry of Abyssal Plains. Geol. Soc. Spec. Publ. London, 31.

\section{Ms 157IR-101}

